\title{
放線菌感染が誘因と考吕られた振子様扁桃症例
}

\author{
平井 滋夫 ・秋定健 - 吉弘 剛 \\ 武 浩太郎・折田 洋造
}

\section{A Case Report of a Pendulous Tonsil Induced by Actinomyces Infection}

\author{
Shigeo Hirai, Takeshi Akisada, Tsuyoshi Yoshihiro, \\ Kotaro Take and Yozo Orita
}

(Kawasaki Medical School)

\begin{abstract}
A 63-year-old woman visited our clinic complaining of a pharyngeal growth of a few months duration. The tumor grew gradually at first, but then became larger and grew rapidly.

This tumor had arisen from the right palatine tonsil.

After surgical extirpation, pathological examination revealed tonsil-like tissues and the presence of a few Actinomyces drusen.
\end{abstract}

Key words : Actinomyces, palatine tonsil, pendulous tonsil

はじめに

振子様扁桃は，1885年に Jurasz ${ }^{11}$ により初めて報告さ れ，1898年に Finder ${ }^{2)}$ にり「扁桃がその茎により咽 頭腔に懸垂するものである.」と定義されて以来, 本邦 でも相次いで報告があった．そこで様々な定義，分類が なされ，成因などについて議論されてきた。しかし，現 在その成因については明確にされていない，今回我々は， 摘出後病理組織学的に放線菌菌体が確認された振子様扁 桃を経験したので，若干の文献的考察を加えて報告する．

\section{症例}

症例 : 63歳, 女性.

主訴：咽頭異物感.

既往歴 : 特記すべきことなし。

家族歷：特記すべきことなし。

現病歴：1997年 1 月中旬より咽頭異物感が出現するも 放置. その後, 症状増悪してきたため 1 月 30 日近医受診. 内服等にて経過みるも腫瘤の大きさが急激に増大してき
たため， 3 月 11 日当科紹介受診となる.

咽頭所見：右口蓋扁桃より，正中を越兄て咽頭腔へ懸 垂する，可動性のある有茎性腫瘤を認めた(図 1 ).

全身所見：特記すべきことなし．

検查所見：血液一般，尿検查等異常を認めなかった。 1997年 3 月 18 日，全身麻酔下に両口蓋扁桃摘出術を施 行した.

摘出患側扁桃の肉眼所見：振子部 $1.8 \times 1.5 \mathrm{~cm}$, 母扁 桃部 $2.5 \times 1.5 \mathrm{~cm}$. 振子部は弾性硬, 表面平滑で淡紅白 色を呈していた(図2).

患側扁桃の病理組織学的所見 : 振子部は肉芽組織が形 成された扁桃組織像で，その茎部の母扁桃側にいくつか のActinomyces の菌塊を認めた．菌塊は陰窩内に存在し， 菌塊外層に放線状構造, 周辺には炎症細胞浸潤を認めた。 炎症細胞は陰窩上皮内にも認められた（図 3 ). 肧中心は 拡大し，それは所々で不明瞭であった。 


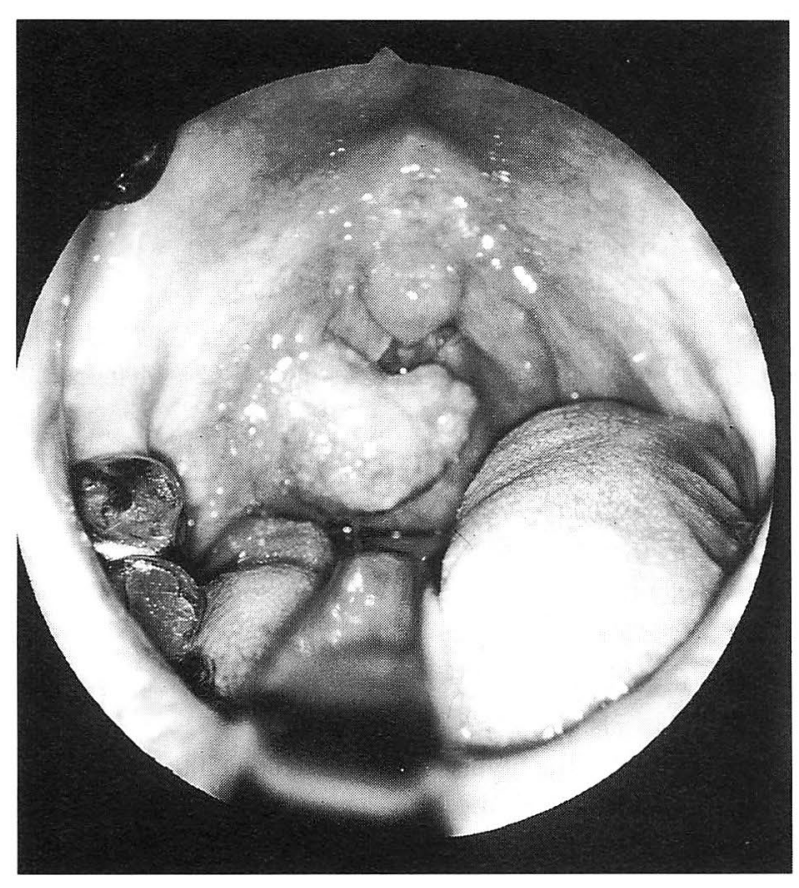

図 1 咽頭所見

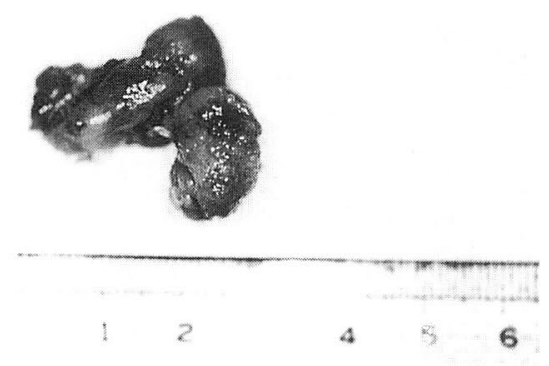

図 2 摘出患側扁桃の肉眼所見

\section{考察}

Finder ${ }^{2)}$ により定義されて以来, 本邦では様々な振子 様扁桃の分類がなされた. 上田ら ${ }^{3)}$ は次の 2 型に分類し ているＩ型は扁桃自体が有茎となる場合(真性振子様 扁桃)で，II型は母扁桃から一部が有茎性に突出する場 合(いわゆる振子様扁桃)である. 小田ら出は口蓋扁桃の 肥大を定型的, 非定型的の 2 つに分類し, 後者の中に上 田の I 型, II型および振子様腫瘤等を含む形としている.

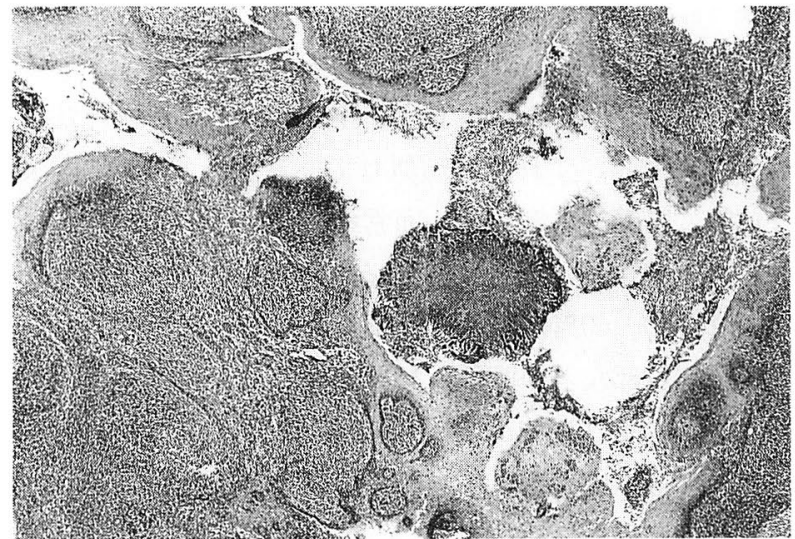

図 3 患側扁桃の病理組織学的所見 (HE 染色, 20倍)

最近では(1)真性振子様扁桃(2)いわゆる振子様扁桃(3)振子 様腫瘤の 3 型に分類することが多い。交た病理組織学的 には，振子部が母扁桃と同一組織であるものを狭義の振 子様扁桃とし，そうでないものを広義のものとしてい る5)。自験例では振子部は母扁桃之同一組織であり，狭 義の振子様扁桃之言える. また母扁桃から一部が有茎性 に突出して扣り，“いわゆる振子様扁桃”に分類される.

発生年齢は佐々 小 $^{6}$ によると, 94例中 10 歳代 28 例, 20 歳代31例と $10 \sim 20$ 歳代が半数を占めている.つまり本疾 患は若年性に好発すると言える。自験例は63歳であるが， 腫瘤の大ささが初期の段階では小さかったため, 自覚症 状の出現が遅延したものと考光られた.

発生部位は，西端ら ${ }^{7)} に よ る と 104$ 例中99例が口蓋扁 桃上極であり，圧倒的に上極が多いと言える、口蓋扁桃 以外では耳管咽頭ひだより発生したものを広重ら ${ }^{8)}$ が報

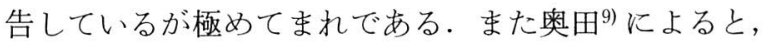
発生部位に左右差はなく，注とんどが片側性であり，ま れに両側性に発生する.自験例では片側口蓋扁桃の上極 より発生して拈り，本邦ではよく見られるタイプであっ た。

振子様扁桃の発生機序については, 従来から 2 つの説 がある. (1)先天性奇形説10) 14) と(2)炎症性刺激説 1)2)15) 18) である. (1)は, 胎生 2 カ月で口蓋扁桃原基がつくられ, 生後 3 力月頃に扁桃萌芽を出す際に何らかの原因で有茥 性に増殖する部位が生じる。 そして, 思春期以後に母扁 桃が退行変性を起こしても, 増殖部位は退行せず増殖を 続けるといら説である。(2)は，炎症性刺激を繰り返すた めに生じた，異型性の扁桃肥大であるといら説である. 
我々は自験例での誘因を放線菌と考えるが，それを論 ずる前に一般的な放線菌症について述べる。まず，放線 菌Actinomyces とは分類上は真性細菌に属するが，細菌 拉よび真菌のいずれにも類似している菌である ${ }^{19)}$. 同菌 は口腔，腸管等に常在し，通常病原性は無いが何らかの 機会に放線菌症として発症する ${ }^{20)}$. 放線菌症は山田ら ${ }^{21}$ によれば50〜 60\%が口腔，䭭部および頸部等に発症し， $22 \%$ が回盲部などの腹部，15\%が胸部であったと報告し ている.つまり半数が頭頸部領域であるが，口蓋扁桃に 発症したものは非常にまれであり，本邦において我々が 検索し得た範囲では，光本 ${ }^{22)}$, 有福 ${ }^{23)}$, 森川ら ${ }^{24)}$ の報告 を見るのみである．現在，扁桃放線菌症の診断基準とし て確定したものは無いが，森川ら ${ }^{24)}$ が次のよらに挙げ ている. (1)臨床症状 : 局所の腫脹, 発赤, 疼痛, 硬結, 潰瘍, 瘦孔形成など，(2)細菌学的検査 : 膿汁中からの放 線菌の菌塊の証明，培養による放線菌の分離，(3)病理組 織学的検査 : 実質内の菌塊の証明, 菌塊外層の放線状構 造, 菌塊周囲の炎症細胞浸潤.

次に，自験例でこれらに該当するものは臨床症状とし ては局所の腫脹, 病理組織学的検査としては菌塊外層の 放線状構造，菌塊周囲の炎症細胞浸潤である。つまり扁 桃実質内には菌塊を証明できて扣らず，扁桃放線菌症と 診断できるものではない。また，一般的に慢性扁桃炎の 摘出後標本でも常在菌である放線菌菌体は散見できる.

しかし，自験例においては放線菌菌体が振子部頸部の母 扁桃側に確認できたこと，その菌体周囲に炎症細胞浸潤 を認めたことより，我々は放線菌感染が振子様扁桃発生 の誘因となっているものと考えた。また振子部が $2 \sim 3$ 日で急激に増大していることからも，放線菌感染による 炎症性刺激が存在したと考兄られた。

\section{まとめ}

(1)病理組織学的に放線菌菌体が確認された振子様扁桃 症例を報告した。

(2)放線菌菌体周辺に炎症細胞を認めたことや，振子部 の大きさが急激に増大したこと等より，その炎症性刺激 が振子様扁桃発生の誘因であると考兄られた。

\section{参考文献}

1) Jurasz A: Casuistische Beitrage zur Lehre von den Anomalien der Gaumentonsillen. Mschr f Ohrenhk 19 : $361 \sim 365,1885$
2) Finder G : Zur pathologischen Anatomie der Tonsille. Arch f Laryng $8:$ 354 361, 1898.

3 ）上田直昭, 金林秀明 : 所謂振子様扁桃. 広島医学 $19: 374$ $\sim 379,1966$.

4) 小田雅義, 鈴木政昭, 斎藤 等: 口蓋扁桃の異型肥大の 1 症例. 耳喉 $37: 51 \sim 53,1965$.

5 ) 赤木博文, 西崎和則, 増田 游: 特殊な扁桃肥大一振子 様扁桃・乳頭状扁桃肥大一. JOHNS 12 : 977 980, 1996.

6 ）佐々木庸一：振子様扁桃の 1 症例. 日耳鼻 $62: 1400 \sim 1402$, 1960.

7 ) 西端慎一, 池上彰博, 高橋広臣 : 口蓋扁桃の振子様腫瘤(振 子様扁桃)の 2 例. 耳喉 $53: 1133 \sim 1136,1981$.

8 ) 広重徳子, 荒木真哉：珍しい振子様扁桃(耳管咽頭ひだよ り発生)の症例 一教室に打ける振子様扁桃の統計につい て一. 耳鼻臨床 71 : 943〜 949, 1978.

9 ）奥田信一：両側にみたいわゆる振子様扁桃の 1 症例. 耳鼻 臨床 $48: 71 \sim 73,1955$

10) Iwanoff $P A:$ Die atypischen Hypertrophien der Mandeln. Laryngol Rhinol Otol 2 : 29 32, 1910.

11）内藤 售, 松永 亨, 音在秀信, 他: 振子様扁桃腺 2 例. 日耳鼻 $64: 1563 \sim 1566,1961$

12）吉田 一：振子様口蓋扁桃腺の 1 例. 耳喉 $6: 226 \sim 229$, 1933.

13）蒲島敏雄：巨大なる振子様口蓋扁桃腺の 1 例. 耳喉 10 : $732 \sim 741,1937$.

14）赤池清美, 桶口 武, 大塚鯉三 : 振子様口蓋扁桃腺の 3 例. 日耳鼻 $53: 173 \sim 177,1950$.

15）浅井 實: 振子様口蓋扁桃腺の 2 例. 耳鼻 $3: 217 \sim 223$, 1930.

16）白川吾一郎，大北 要：振子様扁桃腺に就いて。耳喉 3 : 224 227, 1930.

17）中村文雄, 丸岡省三: 振子様扁桃腺の組織学的所見. 耳喉 $12: 1023 \sim 1029,1939$.

18）渡辺 晋, 柴田浩一, 林田邦彦: 振子様扁桃の 3 症例 一病 理組織学的検討一. 日耳鼻 $77: 232 \sim 236,1974$.

19）戸田忠男, 武谷健二 : 戸田新細菌学. 467～470頁, 南山堂, 東京, 1974 .

20）小川晃弘, 赤木博文, 西崎和則, 他: 頸部肉芽性病变を併 発した扁桃放線菌症の 1 例. 耳鼻 $43: 193 \sim 199,1997$.

21）山田篤伸, 坂東 守, 松村祐二郎 : 頸部 - 顔面に打ける放 線菌症例. 耳鼻 $17: 179 \sim 184,1971$.

22) 光本 乾: 口腔扁桃放線菌症の 1 例. 広島医学 $16: 92$, 1963.

23）有福 裕：放線菌による両急性扁桃腺炎の 1 例. 日耳鼻 $67: 651,1964$.

24）森川郁郎, 進 武幹, 渡辺 宏, 他 : 口蓋扁桃に見られた 放線菌症とその診断. 耳鼻 $31: 382 \sim 386,1985$.

$$
\left(\begin{array}{l}
\text { 別刷請求先 : 平井滋夫 } \\
\text { T701-0192 倉敷市松島577 } \\
\text { 川崎医科大学耳鼻咽喉科学教室 }
\end{array}\right)
$$

